\title{
Cellular Organelles Involved in Hepatitis E Virus Infection
}

\author{
Xing Liu, Menghang Wang and Xin Yin*(D) \\ State Key Laboratory of Veterinary Biotechnology, Harbin Veterinary Research Institute, Chinese Academy of \\ Agricultural Sciences, Harbin 150069, China; liuxingshenglin@163.com (X.L.); wmhtcs@163.com (M.W.) \\ * Correspondence: yinxin@caas.cn
}

Citation: Liu, X.; Wang, M.; Yin, X. Cellular Organelles Involved in Hepatitis E Virus Infection. Pathogens 2021, 10, 1206. https://doi.org/ 10.3390 / pathogens10091206

Academic Editors: Sven Pischke, Lin Wang and Jerome Gouttenoire

Received: 21 August 2021

Accepted: 16 September 2021

Published: 17 September 2021

Publisher's Note: MDPI stays neutral with regard to jurisdictional claims in published maps and institutional affiliations.

Copyright: (c) 2021 by the authors. Licensee MDPI, Basel, Switzerland. This article is an open access article distributed under the terms and conditions of the Creative Commons Attribution (CC BY) license (https:// creativecommons.org/licenses/by/ $4.0 /)$.

\begin{abstract}
Hepatitis E virus (HEV), a major cause of acute hepatitis worldwide, infects approximately 20 million individuals annually. HEV can infect a wide range of mammalian and avian species, and cause frequent zoonotic spillover, increasingly raising public health concerns. To establish a successful infection, HEV needs to usurp host machineries to accomplish its life cycle from initial attachment to egress. However, relatively little is known about the HEV life cycle, especially the functional role(s) of cellular organelles and their associated proteins at different stages of HEV infection. Here, we summarize current knowledge regarding the relation of HEV with the different cell organelles during HEV infection. Furthermore, we discuss the underlying mechanisms by which $\mathrm{HEV}$ infection is precisely regulated in infected cells and the modification of host cell organelles and their associated proteins upon HEV infection.
\end{abstract}

Keywords: hepatitis E virus; cellular organelles; life cycle

\section{Introduction}

Hepatitis E Virus (HEV), a single-stranded, positive-sense RNA virus, is now recognized as a significant cause of acute viral hepatitis in both developing and industrialized regions, leading to 20 million infections, more than 3 million cases of hepatitis $\mathrm{E}$, and 70,000 deaths annually [1,2]. It is usually transmitted via the fecal-oral route either by consumption of contaminated food or water or by direct person-to-person contact [3-5]. The HEV within the Orthohepevirus A genus has been subdivided into at least 8 genotypes. Genotypes 1 and 2 have been detected exclusively in humans, whereas genotypes 3 and 4 circulate among humans and other animal species including pig, deer, rabbit, monkey, cow, goat, and wild boar [6-12]. Genotypes 5 and 6 infect wild boar without reports showing zoonotic transmission to humans [13]. Genotypes 7 and 8 are known to infect dromedary and Bactrian camels with potential zoonotic risk $[14,15]$. In recent years, the reported cases of HEV infection have been steadily increasing globally, especially in developed countries [16]. Despite this public health threat, no specific treatment modalities are available currently $[17,18]$. Therefore, deepened understanding of the molecular underpinnings of $\mathrm{HEV}$ replication cycle, as well as of the molecular interactions with host cellular machineries, is critical to developing novel therapeutic interventions against HEV infection.

HEV has long been known to be a non-enveloped virus since its discovery in the 1980s [19]. Recently, a membrane-associated, quasi-enveloped form of virus particles (eHEV) was identified in the bloodstream of infected individuals and culture supernatants, which mediates virus spread within the host [20], while non-enveloped virions are present in feces of infected patients for stable transmission from person-to-person [21,22]. Notably, unlike classical enveloped viruses such as influenza viruses, hepatitis $C$ virus (HCV), and zika virus, which have surface viral proteins embedded in the lipid membrane, eHEV has no viral antigens on its surface and is resistant to neutralizing antibodies [23-25]. The presence of two different virus particles in infected individuals demonstrates that HEV possesses a complex dual life cycle to execute distinct functions for the establishment of successful 
infection. The $7.2 \mathrm{~kb}$ genome of HEV contains a 7-methylguanosine RNA cap at the $5^{\prime}$ end and polyadenylation at the $3^{\prime}$ terminus, as well as three conserved open reading frames (ORFs) termed ORF1, ORF2, and ORF3 [26] (Figure 1). ORF1 encodes a nonstructural polyprotein, pORF1, which contains the methyltransferase (Met), RNA helicase (Hel) and RNA-dependent RNA polymerase ( $R d R p)$, along with several non-enzymatic regions (the ' $Y$ ', ' $X$ ', and 'hypervariable' (HVR) regions) and a putative papain-like cysteine protease (PCP) [27]. ORF2 encodes a glycosylated protein function as secreted antigen (pORF2 ${ }^{\mathrm{S}}$ ) and a capsid structural protein $\left(\mathrm{pORF} 2^{\mathrm{C}}\right.$ ) separately [28]. ORF3 encodes a small multifunctional palmitoylated phosphoprotein required for HEV egress from infected cells [29-31]. In addition to these three conserved ORFs, the genotype 1 HEV harbors an ORF4, which encodes a protein via an internal ribosome entry site (IRES)-like element in response to endoplasmic reticulum (ER) stress [32].

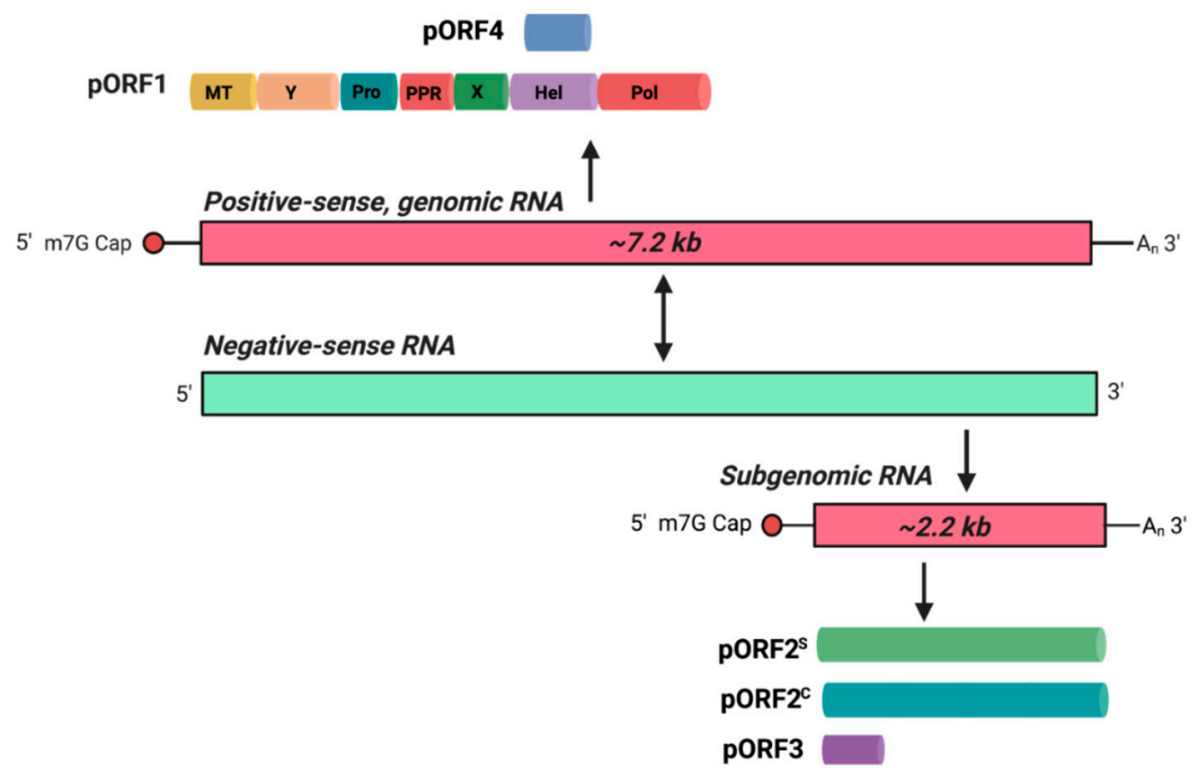

Figure 1. HEV genome, replication, and translation. Hepatitis E virus (HEV) has an $\sim 7.2 \mathrm{~kb}$, positivesense (+) single-stranded genomic RNA, which contains ORF1, ORF2 and ORF3 as described below, plus ORF4, an additional ORF unique to HEV genotype 1 that translates pORF4 promoting virus infection upon endoplasmic reticulum (ER) stress stimulation. Genomic RNA has a 7-methylguanosine (m7G) Cap at the 5' end and is polyadenylated at the 3' end. After viral entry and uncoating, the positive-sense full-length viral genome is translated by host ribosomes to produce a polyprotein pORF1 that contains Met, Hel, RdRp, ' $Y^{\prime}$, ' $X$ ', 'HVR', and putative PCP domains. pORF1 transcribes a negative-sense (-) intermediate RNA from the positive-sense strand. The negative-sense strand then serves as a template for the transcription of numerous positive-sense RNA genomes for packaging into new progeny virions, as well as an $\sim 2.2 \mathrm{~kb}$ subgenomic RNA (sgRNA) containing ORF2 and ORF3, while ORF3 entirely overlaps with ORF2 except for one leading base pair. The sgRNA is also capped at the $5^{\prime}$ end and polyadenylated at the $3^{\prime}$ end, and translates into the capsid protein $\left(\mathrm{pORF}{ }^{\mathrm{C}}\right)$, secreted antigen $\left(\mathrm{pORF} 2^{\mathrm{S}}\right.$ ), and protein ORF3 (pORF3) via a leaky scanning mechanism.

The initial step of the HEV life cycle begins with the specific binding of the virions to the yet unidentified cellular receptors [33]. Given the morphological differences between non-enveloped virus particles and eHEV, it is believed that they utilize distinct pathways to enter target cells [34]. Following internalization, the incoming viral genomes act as templates to produce non-structural polyproteins pORF1 and negative-stranded RNA intermediates for forming the replication and transcription complex [26]. Concordant with the expression of pORF1 from the $7.2 \mathrm{~kb}$ full-length genome [27], the $\mathrm{PORF} 2 \mathrm{C}$ and viroporin pORF3 are translated from a bicistronic $2.2 \mathrm{~kb}$ subgenomic viral RNA to encapsulate the newly produced genomic RNA for assembly $[35,36]$. In addition, $\mathrm{pORF}^{\mathrm{S}}$ was recently 
identified to be translated from the same bicistronic subgenomic RNA through a leaky scanning mechanism, while the functional role(s) of the $\mathrm{PORF}^{\mathrm{S}}$ is still under investigation [28]. Finally, eHEV are egressed from infected cells in an exosomal pathway-dependent manner [37]. Host cellular organelles are principally thought to determine the complete viral life cycle [38]. Nevertheless, the detailed functions of the cellular organelles and their associated proteins remain largely unknown due to the lack of an efficient cell culture system for HEV infection [39]. In this review, we summarize the findings that shape our current understanding of host determinants involved in HEV life cycle, including binding, entry, trafficking, replication, assembly, and release.

\section{Cellular Organelles and Proteins Participating in HEV Binding, Entry, and Uncoating}

2.1. Plasma Membrane and Membrane-Associated Proteins That Mediate HEV Binding and Entry

Plasma membranes are complex architectures consisting of hundreds of lipids and proteins to separate the cell interior from the outside environment [40]. Viruses must hijack the molecules on the plasma membrane to cross membrane barriers; thus, specific interactions between virions and cellular receptors are the first event resulting in the injection of the viral genome into the cytoplasm for productive infection [41]. The molecules with proved relevance for non-enveloped HEV binding include heparin sulfate proteoglycans (HSPGs) [42,43], asialoglycoprotein receptor (ASGPR) [44], and integrin $\alpha 3$ (ITGA3) [45], as shown in Figure 2. Nonetheless, none of them fulfill true bona fide criteria of the virus receptor.

HSPGs, an abundant molecule on the cellular surface of most mammalian cells, served as non-specific attachment factor to facilitate the subsequent interaction between virions with specific receptors [46,47]. Two potential sugar binding sites were mapped in P1 and P2 domains at the HEV capsid protein interface [33]. In addition, removal of cell surface heparan sulfate significantly reduced HEV capsid binding, indicating HSPGs are required for non-enveloped HEV entry [42]. eHEV differ structurally from non-enveloped virions. As expected, HSPG was not required for eHEV infection, suggesting that no potential HSPG binding site existed on the surface of eHEV [34].

Apoliprotein E (ApoE), a core component of plasma lipoproteins that mainly functions in lipoprotein-mediated lipid transport in plasma was found to be upregulated in HEV-infected swine liver by proteomic analysis [48]. Being essential for the transport of cholesterol into and out of the liver, ApoE may be essential for eHEV entry. As reported previously, ApoE participates in the binding of $\mathrm{HCV}$ to specific receptors through its interaction with HCV envelope glycoprotein E2 [49]. More importantly, a study showed that single-nucleotide polymorphisms (SNPs) of ApoE potentially associate with protection against HEV infection in a cohort study [50]. However, another study found that HEV RNA replication and viral production were not affected by ApoE polymorphisms, at least in an Huh-7.5 cell culture model [51].Therefore, the detailed mechanism underlying the observation needs to be further investigated.

ASGPR and ITGA3 that predominately present on the cellular membrane were also identified as dependent factors required for HEV entry and trafficking via different approaches $[44,45]$. siRNA-mediated depletion could significantly reduce HEV binding on the cellular surface, indicating that both ASGPR and ITGA3 act primarily as attachment factors to facilitate HEV entry [44,45]. In addition, HSP90 [52] and ATP5B [53] were shown to directly bind with HEV capsid to mediate intracellular trafficking of incoming virions, but not the binding of HEV virions on the cellular surface. Therefore, these host factors seem to participate in HEV entry at different stages. However, the functional validation of these dependent factors in the context of authentic virus infection is still lacking. 


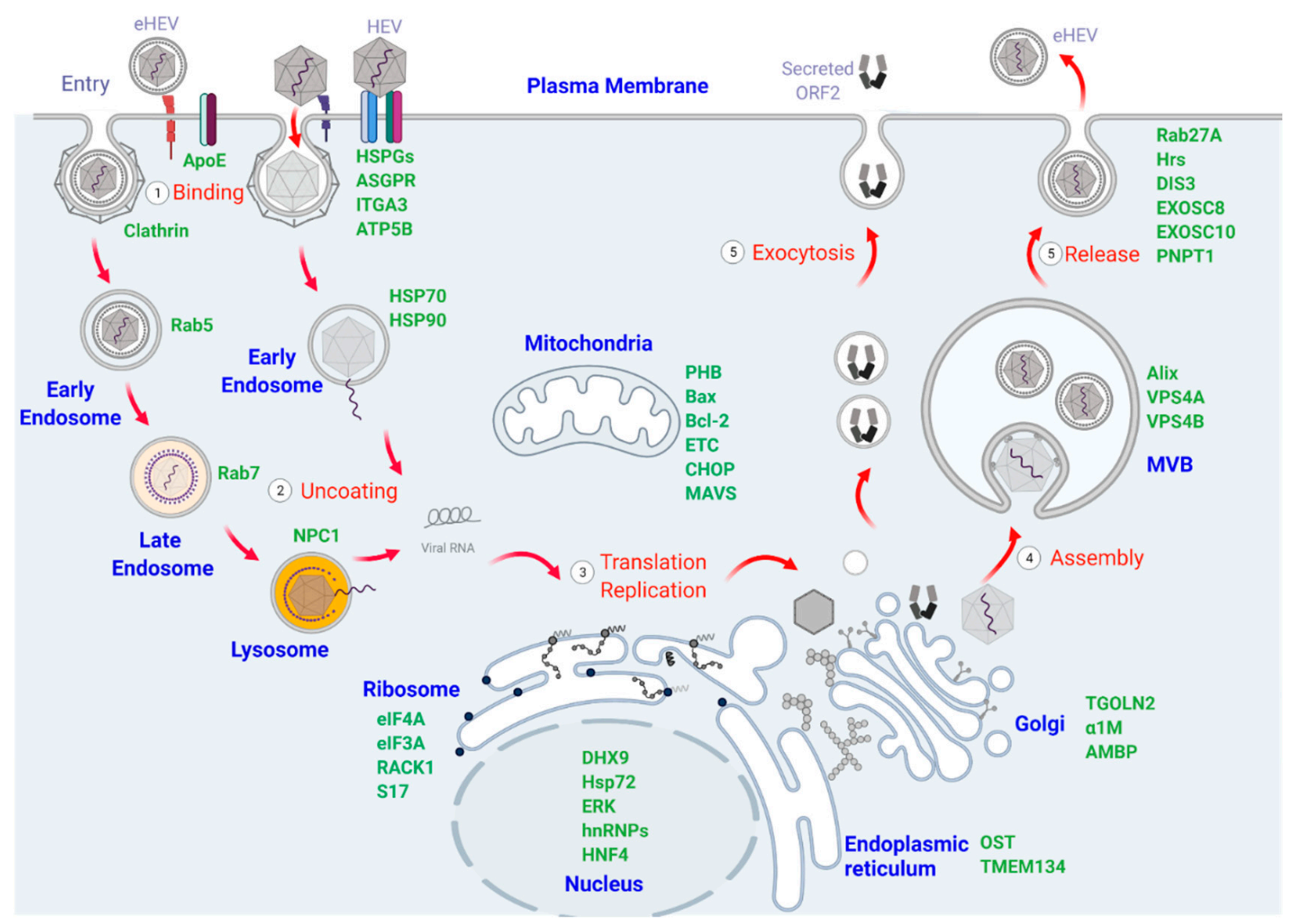

Figure 2. The replicative life cycle of hepatitis E virus. The life cycle of quasi-enveloped HEV (eHEV) and non-enveloped HEV initiates with the binding with cellular membrane proteins, such as ApoE or HSPGs, ASGPR, ITGA3 or ATB5B, respectively to allow virus entry into cells. Both eHEV and HEV are believed to rely on clathrin-mediated endocytosis for internalization. eHEV is trafficked through early- (Rab5+) and late- (Rab7+) endosomes and eventually to lysosomes harboring NPC1 for the uncoating and release of the viral genome into the cytoplasm, while HEV is thought to inject the viral genomes from early endosome to cytoplasm. Subsequently, translation of the pORF1 from incoming viral genomes allows replication to proceed with transcription of the $7.2 \mathrm{~kb}$ genomic and the $2.2 \mathrm{~kb}$ subgenomic RNA through a negativestrand RNA intermediate (-), and translation of the subgenomic RNA to produce the ORF2 and ORF3 encoded proteins in ER (associated with proteins of OST and TMEM134) and ribosome that is promoted by eIF4A, eIF3A and RACK1. Mitochondrial proteins, such as PHB, Bax, Bcl-2, CHOP, MAVS are involved in shaping the microenvironment during HEV replication. HEV infection in cells also triggers the shuttle of host proteins between nucleus and cytoplasm. Secreted ORF2 protein $\left(\mathrm{pORF}^{\mathrm{S}}\right.$ ) is translated from the same bicistronic subgenomic RNA through leaky scanning mechanism and modified in Golgi; then, it is transported outside by exocytosis in dimer. The non-glycosylated ORF2 protein (pORF2 ${ }^{\mathrm{C}}$ ) forms naked virions by self-assembling to capsid and packaging of the viral genome, while eHEV formation requires the engagement of pORF3 and the coating of lipid membrane in multivesicular bodies. Release of eHEV involves exosomal-associating proteins Rab27A, Hrs, DIS3, EXOSC8, EXOSC10, and PNPT1, and fusion with the plasma membrane. Secreted particles remain associated with the lipid membrane in the culture supernatant of infected cells, while HEV remains in cells.

\subsection{Endosomal Vesicles and Related Signaling Pathways Involved in HEV Trafficking}

Endosomes are membrane-bound endocytic organelles inside cells that play key roles in the sorting and delivery of cargos to various intracellular destinations [54]. Both eHEV and non-enveloped HEV heavily rely on endosomal vesicles to deliver the viral genome into infected cells [34]. Our previous study demonstrated that clathrin-mediated endocytosis (CME), which is a common pathway exploited by many viruses $[55,56]$, served as the main entry route for both virions to enter the host cells [34]. Depletion of the core components of CME resulted in reduced infectivity of both eHEV and non-enveloped HEV in hepatocytes. 
In terms of eHEV internalization and trafficking, the small GTPases Rab5 and Rab7 were required [34], suggesting that eHEV moves across the entire endolysosomal network. After endocytic internalization and endosomal sorting, the internalized eHEV was targeted to the lysosome that had the proper environmental conditions to trigger its membrane degradation, resulting in access of the exposed capsid to intracellular receptors for eventual uncoating [34]. Niemann-Pick C1 (NPC1), a lysosomal cholesterol transporter, was verified to be essential for efficient infection of eHEV, as depletion of NPC1 reduced eHEV but not HEV infectivity in hepatocytes [34]. More recently, it was shown that phosphatidylserine receptor-Hepatitis A Virus Cellular Receptor 1 (HAVCR1) and NPC1 participated in quasienveloped hepatitis a virus (HAV) infection by an undefined mechanism that mediates the delivery of genetic material into the cytoplasm [57]. Therefore, the HAVCR1-NPC1 pathway appears to represent a common mechanism for cell entry of both quasi-enveloped $\mathrm{HAV}$ and eHEV.

Non-enveloped HEV has been established to rely on CME as the main entry route to enter hepatocytes [34]. Subsequently, non-enveloped HEV stop at an undefined compartment near plasma membrane for uncoating. Further research is required to identify the virus-specific factors responsible for the entry and trafficking of both non-enveloped HEV and eHEV. Given the rapid innovation in live-imaging techniques and labeling of virus components, the detailed functions of membrane-associated proteins in HEV entry will be uncovered shortly.

\section{Cellular Organelles and Proteins Involved in HEV Translation and Replication}

\subsection{Endoplasmic Reticulum and ER-Resident Proteins Involved in HEV Translation and Replication}

The ER is a membranous system that mediates the biosynthesis of membrane and secreted proteins, as well as lipids such as fatty acids, sphingolipids, phospholipids, and cholesterol $[58,59]$. The synthesis of approximately one-third of all cellular proteins is governed in this organelle [58]. As obligate parasites that solely rely on host machineries to thrive and produce progeny virions, almost all viruses usurp the endogenous functions of numerous ER-resident channels, chaperones, and enzymes throughout the whole viral life cycle [60-63]. Confocal imaging revealed that the overexpressed non-structural polyprotein pORF1 predominately co-localized with ER marker BAP31 [64], indicating that ER is likely to be a central organelle that governs HEV replication. As a positive-sense RNA virus, after uncoating, pORF1 is immediately translated from the $7.2 \mathrm{~kb}$ RNA genome to produce RdRp for viral RNA synthesis [26]. Thus, the ER localization of pORF1 indicated that ER may act as a viral factory for the synthesis of the key viral components.

Multiple ER-associated proteins interacting with HEV encoded proteins were discovered to modulate viral replication upon infection [31,32,64-69]. It seems that ER-resident enzymes, such as the oligosaccharyl transferase (OST) complex, drive the attachment of glycan moieties to the nascent $\mathrm{pORF} 2^{S}$ for glycosylation modification $[70,71]$. Treatment with Brefedin A, a protein transport inhibitor, dramatically reduced glycosylated ORF2 protein secretion [72]. The folded and glycosylated ORF2 proteins then exit the ER by packaging into coat protein complex II (COPII)-coated vesicles, and then transit through the classical secretory pathway en route to efficient secretion. Intriguingly, the ER-associated degradation pathway was also reported to regulate the retro-translocation of $\mathrm{pORF} 2^{\mathrm{S}}$ from the ER lumen to the cytosol without validation in the context of bona fide infection [70]. Transmembrane protein 134 (TMEM134), an ER-associated protein, was identified as a partner of pORF2 ${ }^{C}$ via a split-ubiquitin yeast two-hybrid screening [68]. It is proposed that TMEM134 negatively regulates pORF2 ${ }^{\mathrm{C}}$-mediated inhibition of the NF- $\mathrm{kB}$ signaling pathway [68].

pORF1 and pORF3 contain multiple predicted palmitoylation sites. Removal of the putative palmitoylation sites at residues C336-C337 of pORF1 protein was lethal to HEV infection in HepG2/C3A [73]. The HEV variant with mutations at the palmitoylation sites within pORF3 lost its ability to egress from infected cells [29]. Therefore, palmitoylation modification is essential for $\mathrm{HEV}$ infection via maintaining the stability and functions 
of pORF1 and pORF3 [29,73]. As reported previously, the zinc finger Asp-His-His-Cys (DHHC) domain-containing palmitoyltransferases (ZDHHCs) that display ER and/or Golgi localization govern palmitoylation modification [74]. It remains to be determined which ER-resident ZDHHCs is responsible for processing.

ER stress stimulated by thapsigargin or tunicamycin induces a cap-independent, internal initiation-mediated translation of a novel viral protein known as PORF4 in HEVinfected cells [32]. The pORF4 protein is specifically encoded by genotype-1 HEV and directly interacts with eEF1 $\alpha 1$ to stimulate RdRp activity, leading to enhanced replication [32]. These results indicate that the ER and ER-resident proteins play essential roles in the HEV life cycle via modulation of virally encoded proteins.

\subsection{Ribosomes and Associated Factors Necessary for Translation of HEV Proteins}

Ribosomes are central apparatuses that catalyze protein synthesis [75]. The synthesis of viral proteins heavily depends on the functions of the host ribosomes [76]. A set of host translation factors such as eIF4A, eIF3A, and ribosomal protein receptor for activated C kinase 1(RACK1) were identified as key players supporting HEV replication [77]. Translation initiation protein eIF4A forms the eIF4F translation initiation complex together with the large scaffolding protein eIF4G and the cap-binding protein eIF4E to drive the cap-dependent translation initiation [78]. The natural compound silvestrol, a specific inhibitor of eIF4A, exhibited a potent antiviral effect against HEV replication in vitro and in vivo via preventing enzymatic unwinding of eIF4A $[79,80]$. RACK 1 , a protein of the $40 \mathrm{~S}$ ribosomal subunit, promoted translation of $\mathrm{HCV}$ and poliovirus $[81,82]$. Upon protein kinase C-mediated stimulation, activated RACK1 initiated the following: PKC $\beta$ II complex phosphorylates eIF4G at $\mathrm{S} 1093$ in the tight $48 \mathrm{~S}$ initiation complex, possibly facilitating dissociation/recycling of eIF4F [83]. However, the precise role of RACK1 in HEV replication remains unclear.

In addition to regulating viral protein translation, the insertion of a ribosome protein sequence appears to play vital roles in mediating cross-species infection by certain HEV strains. Insertion of a 171-nucleotide sequence encoding amino acids 21 to 76 of the human ribosomal protein $\mathrm{S} 17$ within the hypervariable region (HVR) of HEV pORF1 contributed to the adaptation of HEV strain Kernow C-1 P6 in cell lines from different animal species [84]. Furthermore, lysine residues within the human ribosomal protein S17 sequence were responsible for enhanced virus replication [85]. Notably, an RNA sequence encoding ribosomal protein S19 was also found in the HVR of the HEV GT3 strain LBPR-0379 [86]. These observations suggest that HEV viral quasi-species capable of enhanced levels of virus replication can be produced by the insertion of RNA sequences encoding cellular ribosomal proteins. The mechanisms underlying the enhanced levels of HEV replication are still unknown.

\subsection{Mitochondria and Related Signaling Participating in HEV Infection}

Mitochondria is a double membrane intracellular organelle that plays multiple important roles in maintaining homeostasis [87]. Increasing evidence demonstrates that mitochondria plays vital roles in antiviral immune responses [88], apoptosis [89], and inflammation [90] induced by virus infection. HEV infection in Mongolian gerbils caused mitochondria swelling and vacuolation via ultrastructural pathological analysis [91]. The mitochondrial damage triggered the apoptosis signaling pathway, leading to the necrosis and cell death of renal epithelial cells in the acute phase of HEV infection [91]. In addition, loss in mitochondrial cristae and swollen mitochondria were observed in HEVinfected hepatocytes via transmission electron microscopy [92]. These results suggest that mitochondrial lesions may be biomarkers of HEV infection.

Quantitative proteomics analysis found that prohibitin (PHB), a critical mitophagy receptor mediating autophagic degradation of mitochondria, was upregulated in HEVinfected livers in a swine model [48]. Pro-apoptotic protein BCL2-associated X protein (Bax) and B-cell lymphoma 2 (Bcl-2), mitochondrion-mediated apoptosis regulating proteins, 
were also induced in the HEV infected gerbils, resulting in the activation of mitochondrial apoptotic pathway and apoptosis [93]. Electron transport chain (ETC), a key component of the mitochondria, positively regulates HEV replication [94]. Pharmacological inhibition of complex III of ETC restricted the replication of HEV [94]. Thus, ETC could be a viable anti-HEV target for therapeutic development. The pro-apoptotic gene C/EBP homologous protein $(\mathrm{CHOP})$ was reported to be activated by pORF2 ${ }^{\mathrm{C}}$ [65]. $\mathrm{CHOP}$ mediates translocation of Bax from cytosol to mitochondria [95]. However, direct evidence is still missing regarding the function of CHOP in HEV replication.

Adaptor protein MAVS, which is crucial for initiating the activation of antiviral innate immune response to RNA virus infection, negatively regulated HEV infection [96]. Unlike other hepatotropic viruses, including $\mathrm{HAV}$ and $\mathrm{HCV}$, which are capable of cleaving MAVS to suppress the signaling activation [97,98], HEV does not target MAVS for degradation [99], but instead disrupts JAK-STAT1 signaling to block interferon-induced genes' (ISGs) expression $[100,101]$. Therefore, mitochondrial dynamics modified by HEV infection determines the outcome of infection.

\subsection{Interactions between HEV Components and the Nucleus during Virus Infection}

HEV appears to complete its whole life cycle outside the nucleus [102]. Surprisingly, HEV pORF2 ${ }^{C}$ was detected in the nucleus by immunohistochemistry; thus, HEV pORF2 ${ }^{C}$ probably associates with nuclear components to regulate viral infection [103]. In addition, DExH-box helicase 9 (DHX9), which localizes in both the nucleus and the cytoplasm, interacts with HEV 3'UTR to function as a transcriptional regulator [104].

$\mathrm{HEV}$ infection seems to trigger the shuttle of the host proteins between nucleus and cytoplasm [65,105-108]. HEV pORF2 ${ }^{\mathrm{C}}$ reportedly interacted with Hsp72 and mediated its nuclear accumulation [65]. The extracellular signal-regulated kinase (ERK), a member of the MAP kinase family of enzymes, displayed enhanced activity and nuclear localization mediated by pORF3 [105]. pORF3 also impaired nuclear translocation of hepatocyte nuclear factor 4 (HNF4) by increasing its phosphorylation through the ERK and Akt kinases, causing down-regulation of HNF4-responsive genes in pORF3-expressing cells [108]. Heterogeneous nuclear ribonucleoproteins (hnRNPs), namely hnRNPK, hnRNPA2B1, hnRNPH, PCBP1, and PCBP2, redistributed from nucleus to cytoplasm in HEV-infected cells [106]. hnRNPK and hnRNPA2B1 interacted with the promoter regions of HEV RNA and HEV polymerase protein to increase HEV RNA replication, while hnRNPH, PCBP1, and PCBP2 only bound with HEV genomic promoter to inhibit viral replication [106]. Consistently, quantitative proteomics analysis showed that hnRNPK was upregulated in HEV-infected cells, indicating that HEV requires plenty of hnRNPK for its efficient replication. However, the outcome of protein shuttling between cytosol and nucleus in HEV life cycle is still unclear. Novel proximity labeling techniques can be applied to dissect the temporal and spatial localization of host proteins in response to HEV infection.

\section{Cellular Organelles and Proteins Involved in HEV Assembly and Release}

\subsection{The Role of the Golgi Apparatus in HEV Assembly}

The assembly process of HEV viral particles has garnered much attention, but it is still largely unknown [33,109-114]. The pORF2 ${ }^{C}$ undergoes post-translational modification in Golgi and self-assembles to capsid, and binds with HEV full-length genomic RNA for encapsulation [115]. The arginine-rich domain in the N-terminal region of the capsid protein and the 5' end of the viral genomic RNA were demonstrated to be responsible for the assembly $[116,117]$. However, host proteins involved in HEV assembly have yet not been identified. $\mathrm{pORF}^{\mathrm{S}}$ serves as a viral secreted antigen with unidentified biological function; it is translated from the same bicistronic subgenomic RNA through a leaky scanning mechanism and post-translated in Golgi, and is then transported outside by exocytosis in dimer [28].

The Golgi apparatus plays a central role in protein transport by regulating cargo sorting and trafficking [118]. Trans-Golgi network protein 2 (TGOLN2), an intracellular 
protein derived from the trans-Golgi network, was enriched on the lipid membrane of eHEV particles [119]; thus, the Golgi apparatus probably participates in the assembly of eHEV. Importantly, the formation of the eHEV recruits pORF3, which is post-translated by phosphorylation and palmitoylation in Golgi. The modified pORF3 may mediate the incorporation of lipid membrane in multivesicular bodies (MVBs) $[31,35,36]$. Liver-specific $\alpha 1$-Microglobulin $(\alpha 1 \mathrm{~m})$ was found to re-distribute in the Golgi compartment in HEV ORF3expressed cells. The HEV pORF3 interacted with $\alpha 1 \mathrm{~m}$ and its precursor $\alpha 1 \mathrm{~m} /$ bikunin precursor (AMBP), mediating the transport [120]. However, the roles of these host proteins in HEV assembly remain unclear. Future study is required to solve questions regarding HEV assembly.

\subsection{Multivesicular Bodies (MVB) and Exosomal Pathways in HEV Egress}

The mechanism underlying HEV egresses from infected cells remains to be determined. Previous studies demonstrated that MVB sorting and the exosomal pathway are key players mediating HEV release from infected cells [30,121,122]. Tumor susceptibility gene 101 (Tsg101), a component in the endosomal sorting complex required for transport (ESCRT) machinery, interacted with HEV pORF3 via the PSAP late domain [123]. In addition, components in the ESCRT complex, such as apoptosis-linked gene 2-interacting protein X (ALIX), VPS4A, and VPS4B, were involved in HEV egress from infected cells [121]. Depletion of either ALIX, VPS4A, or VPS4B decreased the budding efficiency of HEV [121].

eHEV resemble exosomes in size range 50-100 nm from infected cells [37]. GW4869, an inhibitor of exosome biogenesis, blocked HEV egress from HEV-infected cells, indicating that HEV hijacks and customizes the exosomal pathway to promote its budding. Depletion of Rab27A or Hrs, the regulators of exosome secretion, led to reduced HEV budding from infected cells [122]. Rat HEV egress was also suppressed in Rab27A- or Hrs-depleted cells [121]. Notably, the expression levels of the key components of the exosomal pathway, such as exosome endoribonuclease and $3^{\prime}-5^{\prime}$ exoribonuclease (DIS3), exosome component 8 (EXOSC8), exosome component 10 (EXOSC10), and polyribonucleotide nucleotidyltransferase 1 (PNPT1), were elevated in response to HEV infection [104]. Although there is no compelling evidence that supports such a notion, cell lysis may advance the release of non-enveloped HEV as an additional mechanism. Therefore, the majority of HEV particles egress from infected cells by hijacking the exosomal pathway.

\section{Conclusions and Perspectives}

In the last decade, several aspects regarding the life cycle have been propelled forwards by the development of a cell culture system and small animal models. A better understanding of the roles of host organelles and their associated proteins in the HEV life cycle is critical for understanding the pathogenesis and guiding novel strategies for therapy. Therefore, future studies that aim to delineate the cellular receptors, the interaction network between HEV encoded protein, and host proteins are warranted. Although ribavirin therapy is favorable clinically, more active compounds are still urgently needed. Drugs that can directly disrupt the functions of host machinery required for HEV infection should be considered.

Author Contributions: Writing — original draft preparation, X.L., X.Y.; writing—review and editing, X.L., M.W., X.Y.; visualization, X.Y.; supervision, X.Y.; funding acquisition, X.Y. All authors have read and agreed to the published version of the manuscript.

Funding: This work was supported by the National Natural Science Foundation of China (NSFC) [32172940(XY)] and State Key Laboratory of Veterinary Biotechnology Foundation. The funders had no role in study design, data collection and analysis, decision to publish, or preparation of the manuscript.

Acknowledgments: We thank Yuan Pu from Sanford Burnham Prebys Medical Discovery Institute for suggestions and critical reading of the manuscript. The figures were created with BioRender.com.

Conflicts of Interest: The authors declare no conflict of interest. 


\section{References}

1. WHO. Hepatitis E. Available online: https://www.who.int/news-room/fact-sheets/detail/hepatitis-e (accessed on 27 July 2021).

2. Li, P.; Liu, J.; Li, Y.; Su, J.; Ma, Z.; Bramer, W.M.; Cao, W.; de Man, R.A.; Peppelenbosch, M.P.; Pan, Q. The global epidemiology of hepatitis E virus infection: A systematic review and meta-analysis. Liver Int. 2020, 40, 1516-1528. [CrossRef]

3. Primadharsini, P.P.; Nagashima, S.; Okamoto, H. Mechanism of Cross-Species Transmission, Adaptive Evolution and Pathogenesis of Hepatitis E Virus. Viruses 2021, 13, 909. [CrossRef] [PubMed]

4. Treagus, S.; Wright, C.; Baker-Austin, C.; Longdon, B.; Lowther, J. The Foodborne Transmission of Hepatitis E Virus to Humans. Food Environ. Virol. 2021, 13, 127-145. [CrossRef] [PubMed]

5. Teshale, E.H.; Grytdal, S.P.; Howard, C.; Barry, V.; Kamili, S.; Drobeniuc, J.; Hill, V.R.; Okware, S.; Hu, D.J.; Holmberg, S.D. Evidence of person-to-person transmission of hepatitis E virus during a large outbreak in Northern Uganda. Clin. Infect. Dis. 2010, 50, 1006-1010. [CrossRef]

6. Clayson, E.T.; Innis, B.L.; Myint, K.S.; Narupiti, S.; Vaughn, D.W.; Giri, S.; Ranabhat, P.; Shrestha, M.P. Detection of hepatitis E virus infections among domestic swine in the Kathmandu Valley of Nepal. Am. J. Trop. Med. Hyg. 1995, 53, 228-232. [CrossRef] [PubMed]

7. Neumann, S.; Hackl, S.S.; Piepenschneider, M.; Vina-Rodriguez, A.; Dremsek, P.; Ulrich, R.G.; Groschup, M.H.; Eiden, M. Serologic and Molecular Survey of Hepatitis E Virus in German Deer Populations. J. Wildl. Dis. 2016, 52, 106-113. [CrossRef]

8. Geng, Y.; Zhao, C.; Song, A.; Wang, J.; Zhang, X.; Harrison, T.J.; Zhou, Y.; Wang, W.; Wang, Y. The serological prevalence and genetic diversity of hepatitis E virus in farmed rabbits in China. Infect. Genet. Evol. 2011, 11, 476-482. [CrossRef]

9. Yamamoto, H.; Suzuki, J.; Matsuda, A.; Ishida, T.; Ami, Y.; Suzaki, Y.; Adachi, I.; Wakita, T.; Takeda, N.; Li, T.C. Hepatitis E virus outbreak in monkey facility, Japan. Emerg. Infect. Dis. 2012, 18, 2032-2034. [CrossRef] [PubMed]

10. Huang, F.; Li, Y.; Yu, W.; Jing, S.; Wang, J.; Long, F.; He, Z.; Yang, C.; Bi, Y.; Cao, W.; et al. Excretion of infectious hepatitis E virus into milk in cows imposes high risks of zoonosis. Hepatology 2016, 64, 350-359. [CrossRef]

11. Long, F.; Yu, W.; Yang, C.; Wang, J.; Li, Y.; Li, Y.; Huang, F. High prevalence of hepatitis E virus infection in goats. J. Med. Virol. 2017, 89, 1981-1987. [CrossRef]

12. Di Pasquale, S.; De Santis, P.; La Rosa, G.; Di Domenico, K.; Iaconelli, M.; Micarelli, G.; Martini, E.; Bilei, S.; De Medici, D.; Suffredini, E. Quantification and genetic diversity of Hepatitis E virus in wild boar (Sus scrofa) hunted for domestic consumption in Central Italy. Food Microbiol. 2019, 82, 194-201. [CrossRef]

13. Meng, X.J. Expanding Host Range and Cross-Species Infection of Hepatitis E Virus. PLoS Pathog. 2016, 12, e1005695. [CrossRef] [PubMed]

14. Rasche, A.; Saqib, M.; Liljander, A.M.; Bornstein, S.; Zohaib, A.; Renneker, S.; Steinhagen, K.; Wernery, R.; Younan, M.; Gluecks, I.; et al. Hepatitis E Virus Infection in Dromedaries, North and East Africa, United Arab Emirates, and Pakistan, 1983-2015. Emerg. Infect. Dis. 2016, 22, 1249-1252. [CrossRef]

15. Wang, L.; Teng, J.L.L.; Lau, S.K.P.; Sridhar, S.; Fu, H.; Gong, W.; Li, M.; Xu, Q.; He, Y.; Zhuang, H.; et al. Transmission of a Novel Genotype of Hepatitis E Virus from Bactrian Camels to Cynomolgus Macaques. J. Virol. 2019, 93, e02014-18. [CrossRef]

16. Dalton, H.R.; Seghatchian, J. Hepatitis E virus: Emerging from the shadows in developed countries. Transfus. Apher. Sci. 2016, 55, 271-274. [CrossRef] [PubMed]

17. Kamar, N.; Pischke, S. Acute and Persistent Hepatitis E Virus Genotype 3 and 4 Infection: Clinical Features, Pathogenesis, and Treatment. Cold Spring Harb. Perspect. Med. 2019, 9, a031872. [CrossRef] [PubMed]

18. Todt, D.; Meister, T.L.; Steinmann, E. Hepatitis E virus treatment and ribavirin therapy: Viral mechanisms of nonresponse. Curr. Opin. Virol. 2018, 32, 80-87. [CrossRef]

19. Wands, J.R. Non-A, non-B hepatitis. Hepatology 1983, 3, 764-766. [CrossRef] [PubMed]

20. Takahashi, M.; Tanaka, T.; Takahashi, H.; Hoshino, Y.; Nagashima, S.; Jirintai, F.; Mizuo, H.; Yazaki, Y.; Takagi, T.; Azuma, M.; et al. Hepatitis E Virus (HEV) strains in serum samples can replicate efficiently in cultured cells despite the coexistence of HEV antibodies: Characterization of HEV virions in blood circulation. J. Clin. Microbiol. 2010, 48, 1112-1125. [CrossRef]

21. Takahashi, M.; Yamada, K.; Hoshino, Y.; Takahashi, H.; Ichiyama, K.; Tanaka, T.; Okamoto, H. Monoclonal antibodies raised against the ORF3 protein of hepatitis E virus (HEV) can capture HEV particles in culture supernatant and serum but not those in feces. Arch. Virol. 2008, 153, 1703-1713. [CrossRef]

22. Balayan, M.S.; Andjaparidze, A.G.; Savinskaya, S.S.; Ketiladze, E.S.; Braginsky, D.M.; Savinov, A.P.; Poleschuk, V.F. Evidence for a virus in non-A, non-B hepatitis transmitted via the fecal-oral route. Intervirology 1983, 20, 23-31. [CrossRef] [PubMed]

23. Bouvier, N.M.; Palese, P. The biology of influenza viruses. Vaccine 2008, 26 (Suppl. 4), D49-D53. [CrossRef] [PubMed]

24. Dearborn, A.D.; Marcotrigiano, J. Hepatitis C Virus Structure: Defined by What It Is Not. Cold Spring Harb. Perspect. Med. 2020, 10, a036822. [CrossRef]

25. Sirohi, D.; Kuhn, R.J. Zika Virus Structure, Maturation, and Receptors. J. Infect. Dis. 2017, 216, S935-S944. [CrossRef] [PubMed]

26. Kenney, S.P.; Meng, X.J. Hepatitis E Virus Genome Structure and Replication Strategy. Cold Spring Harb. Perspect. Med. 2019, 9, a031724. [CrossRef]

27. Sehgal, D.; Thomas, S.; Chakraborty, M.; Jameel, S. Expression and processing of the Hepatitis E virus ORF1 nonstructural polyprotein. Virol. J. 2006, 3, 38. [CrossRef] [PubMed] 
28. Yin, X.; Ying, D.; Lhomme, S.; Tang, Z.; Walker, C.M.; Xia, N.; Zheng, Z.; Feng, Z. Origin, antigenicity, and function of a secreted form of ORF2 in hepatitis E virus infection. Proc. Natl. Acad. Sci. USA 2018, 115, 4773-4778. [CrossRef]

29. Gouttenoire, J.; Pollan, A.; Abrami, L.; Oechslin, N.; Mauron, J.; Matter, M.; Oppliger, J.; Szkolnicka, D.; Thi, V.L.D.; van der Goot, F.G.; et al. Palmitoylation mediates membrane association of hepatitis E virus ORF3 protein and is required for infectious particle secretion. PLoS Pathog. 2018, 14, e1007471. [CrossRef]

30. Glitscher, M.; Hildt, E. Hepatitis E virus egress and beyond-The manifold roles of the viral ORF3 protein. Cell. Microbiol. 2021, e13379. [CrossRef]

31. Ding, Q.; Heller, B.; Capuccino, J.M.; Song, B.; Nimgaonkar, I.; Hrebikova, G.; Contreras, J.E.; Ploss, A. Hepatitis E virus ORF3 is a functional ion channel required for release of infectious particles. Proc. Natl. Acad. Sci. USA 2017, 114, 1147-1152. [CrossRef]

32. Nair, V.P.; Anang, S.; Subramani, C.; Madhvi, A.; Bakshi, K.; Srivastava, A.; Shalimar; Nayak, B.; Kumar, C.T.R.; Surjit, M. Endoplasmic Reticulum Stress Induced Synthesis of a Novel Viral Factor Mediates Efficient Replication of Genotype-1 Hepatitis E Virus. PLoS Pathog. 2016, 12, e1005521. [CrossRef]

33. Guu, T.S.; Liu, Z.; Ye, Q.; Mata, D.A.; Li, K.; Yin, C.; Zhang, J.; Tao, Y.J. Structure of the hepatitis E virus-like particle suggests mechanisms for virus assembly and receptor binding. Proc. Natl. Acad. Sci. USA 2009, 106, 12992-12997. [CrossRef] [PubMed]

34. Yin, X.; Ambardekar, C.; Lu, Y.; Feng, Z. Distinct Entry Mechanisms for Nonenveloped and Quasi-Enveloped Hepatitis E Viruses. J. Virol. 2016, 90, 4232-4242. [CrossRef] [PubMed]

35. Graff, J.; Torian, U.; Nguyen, H.; Emerson, S.U. A bicistronic subgenomic mRNA encodes both the ORF2 and ORF3 proteins of hepatitis E virus. J. Virol. 2006, 80, 5919-5926. [CrossRef]

36. Tyagi, S.; Korkaya, H.; Zafrullah, M.; Jameel, S.; Lal, S.K. The phosphorylated form of the ORF3 protein of hepatitis E virus interacts with its non-glycosylated form of the major capsid protein, ORF2. J. Biol. Chem. 2002, 277, 22759-22767. [CrossRef] [PubMed]

37. Nagashima, S.; Takahashi, M.; Kobayashi, T.; Tanggis; Nishizawa, T.; Nishiyama, T.; Primadharsini, P.P.; Okamoto, H. Characterization of the Quasi-Enveloped Hepatitis E Virus Particles Released by the Cellular Exosomal Pathway. J. Virol. 2017, 91, e00822-17. [CrossRef]

38. Bagchi, P.; Banerjee, I.; Martin-Acebes, M.A. Editorial: Cell Organelle Exploitation by Viruses During Infection. Front. Microbiol. 2021, 12, 675152. [CrossRef]

39. Fu, R.M.; Decker, C.C.; Thi, V.L.D. Cell Culture Models for Hepatitis E Virus. Viruses 2019, 11, 608. [CrossRef]

40. van Deventer, S.; Arp, A.B.; van Spriel, A.B. Dynamic Plasma Membrane Organization: A Complex Symphony. Trends Cell Biol. 2021, 31, 119-129. [CrossRef]

41. Burckhardt, C.J.; Greber, U.F. Virus movements on the plasma membrane support infection and transmission between cells. PLoS Pathog. 2009, 5, e1000621. [CrossRef]

42. Kalia, M.; Chandra, V.; Rahman, S.A.; Sehgal, D.; Jameel, S. Heparan sulfate proteoglycans are required for cellular binding of the hepatitis E virus ORF2 capsid protein and for viral infection. J. Virol. 2009, 83, 12714-12724. [CrossRef] [PubMed]

43. Cao, D.; Meng, X.J. Molecular biology and replication of hepatitis E virus. Emerg. Microbes Infect. 2012, 1, 1-10. [CrossRef] [PubMed]

44. Zhang, L.; Tian, Y.; Wen, Z.; Zhang, F.; Qi, Y.; Huang, W.; Zhang, H.; Wang, Y. Asialoglycoprotein receptor facilitates infection of PLC/PRF/5 cells by HEV through interaction with ORF2. J. Med. Virol. 2016, 88, 2186-2195. [CrossRef] [PubMed]

45. Shiota, T.; Li, T.C.; Nishimura, Y.; Yoshizaki, S.; Sugiyama, R.; Shimojima, M.; Saijo, M.; Shimizu, H.; Suzuki, R.; Wakita, T.; et al. Integrin alpha3 is involved in non-enveloped hepatitis E virus infection. Virology 2019, 536, 119-124. [CrossRef]

46. Christianson, H.C.; Belting, M. Heparan sulfate proteoglycan as a cell-surface endocytosis receptor. Matrix Biol. 2014, 35, 51-55. [CrossRef]

47. Boulant, S.; Stanifer, M.; Lozach, P.Y. Dynamics of virus-receptor interactions in virus binding, signaling, and endocytosis. Viruses 2015, 7, 2794-2815. [CrossRef]

48. Rogee, S.; Le Gall, M.; Chafey, P.; Bouquet, J.; Cordonnier, N.; Frederici, C.; Pavio, N. Quantitative proteomics identifies host factors modulated during acute hepatitis E virus infection in the swine model. J. Virol. 2015, 89, 129-143. [CrossRef]

49. Gong, Y.; Cun, W. The Role of ApoE in HCV Infection and Comorbidity. Int. J. Mol. Sci. 2019, 20, 2037. [CrossRef]

50. Zhang, L.; Yesupriya, A.; Chang, M.H.; Teshale, E.; Teo, C.G. Apolipoprotein E and protection against hepatitis E viral infection in American non-Hispanic blacks. Hepatology 2015, 62, 1346-1352. [CrossRef]

51. Weller, R.; Todt, D.; Engelmann, M.; Friesland, M.; Wedemeyer, H.; Pietschmann, T.; Steinmann, E. Apolipoprotein E polymorphisms and their protective effect on hepatitis E virus replication. Hepatology 2016, 64, 2274-2276. [CrossRef]

52. Zheng, Z.Z.; Miao, J.; Zhao, M.; Tang, M.; Yeo, A.E.; Yu, H.; Zhang, J.; Xia, N.S. Role of heat-shock protein 90 in hepatitis E virus capsid trafficking. J. Gen. Virol. 2010, 91, 1728-1736. [CrossRef]

53. Ahmed, Z.; Holla, P.; Ahmad, I.; Jameel, S. The ATP synthase subunit $\beta$ (ATP5B) is an entry factor for the hepatitis E virus. bioRxiv 2016, 060434. [CrossRef]

54. Neefjes, J.; Jongsma, M.M.L.; Berlin, I. Stop or Go? Endosome Positioning in the Establishment of Compartment Architecture, Dynamics, and Function. Trends Cell Biol. 2017, 27, 580-594. [CrossRef]

55. DeTulleo, L.; Kirchhausen, T. The clathrin endocytic pathway in viral infection. EMBO J. 1998, 17, 4585-4593. [CrossRef] [PubMed]

56. Gao, H.; Shi, W.; Freund, L.B. Mechanics of receptor-mediated endocytosis. Proc. Natl. Acad. Sci. USA 2005, 102, 9469-9474. [CrossRef] 
57. Costafreda, M.I.; Abbasi, A.; Lu, H.; Kaplan, G. Exosome mimicry by a HAVCR1-NPC1 pathway of endosomal fusion mediates hepatitis A virus infection. Nat. Microbiol. 2020, 5, 1096-1106. [CrossRef]

58. Sun, S.; Tang, X.; Guo, Y.; Hu, J. Endoplasmic reticulum composition and form: Proteins in and out. Curr. Opin. Cell Biol. 2021, 71, 1-6. [CrossRef]

59. Chen, S.; Novick, P.; Ferro-Novick, S. ER structure and function. Curr. Opin. Cell Biol. 2013, 25, 428-433. [CrossRef]

60. Eymieux, S.; Blanchard, E.; Uzbekov, R.; Hourioux, C.; Roingeard, P. Annulate lamellae and intracellular pathogens. Cell. Microbiol. 2021, 23, e13328. [CrossRef] [PubMed]

61. Ravindran, M.S.; Bagchi, P.; Cunningham, C.N.; Tsai, B. Opportunistic intruders: How viruses orchestrate ER functions to infect cells. Nat. Rev. Microbiol. 2016, 14, 407-420. [CrossRef] [PubMed]

62. Inoue, T.; Tsai, B. How viruses use the endoplasmic reticulum for entry, replication, and assembly. Cold Spring Harb. Perspect. Biol. 2013, 5, a013250. [CrossRef]

63. Romero-Brey, I.; Bartenschlager, R. Endoplasmic Reticulum: The Favorite Intracellular Niche for Viral Replication and Assembly. Viruses 2016, 8, 160. [CrossRef]

64. Perttila, J.; Spuul, P.; Ahola, T. Early secretory pathway localization and lack of processing for hepatitis E virus replication protein pORF1. J. Gen. Virol. 2013, 94, 807-816. [CrossRef]

65. John, L.; Thomas, S.; Herchenroder, O.; Putzer, B.M.; Schaefer, S. Hepatitis E virus ORF2 protein activates the pro-apoptotic gene CHOP and anti-apoptotic heat shock proteins. PLoS ONE 2011, 6, e25378. [CrossRef] [PubMed]

66. Rehman, S.; Kapur, N.; Durgapal, H.; Panda, S.K. Subcellular localization of hepatitis E virus (HEV) replicase. Virology 2008, 370, 77-92. [CrossRef]

67. Jameel, S.; Zafrullah, M.; Ozdener, M.H.; Panda, S.K. Expression in animal cells and characterization of the hepatitis E virus structural proteins. J. Virol. 1996, 70, 207-216. [CrossRef] [PubMed]

68. Tian, Y.; Huang, W.; Yang, J.; Wen, Z.; Geng, Y.; Zhao, C.; Zhang, H.; Wang, Y. Systematic identification of hepatitis E virus ORF2 interactome reveals that TMEM134 engages in ORF2-mediated NF-kappaB pathway. Virus Res. 2017, 228, 102-108. [CrossRef] [PubMed]

69. Yu, H.; Li, S.; Yang, C.; Wei, M.; Song, C.; Zheng, Z.; Gu, Y.; Du, H.; Zhang, J.; Xia, N. Homology model and potential virus-capsid binding site of a putative HEV receptor Grp78. J. Mol. Model. 2011, 17, 987-995. [CrossRef]

70. Surjit, M.; Jameel, S.; Lal, S.K. Cytoplasmic localization of the ORF2 protein of hepatitis E virus is dependent on its ability to undergo retrotranslocation from the endoplasmic reticulum. J. Virol. 2007, 81, 3339-3345. [CrossRef]

71. Zafrullah, M.; Ozdener, M.H.; Kumar, R.; Panda, S.K.; Jameel, S. Mutational analysis of glycosylation, membrane translocation, and cell surface expression of the hepatitis E virus ORF2 protein. J. Virol. 1999, 73, 4074-4082. [CrossRef]

72. Montpellier, C.; Wychowski, C.; Sayed, I.M.; Meunier, J.C.; Saliou, J.M.; Ankavay, M.; Bull, A.; Pillez, A.; Abravanel, F.; Helle, F.; et al. Hepatitis E Virus Lifecycle and Identification of 3 Forms of the ORF2 Capsid Protein. Gastroenterology 2018, 154, 211-223.e8. [CrossRef]

73. Parvez, M.K. Mutational analysis of hepatitis E virus ORF1 "Y-domain": Effects on RNA replication and virion infectivity. World J. Gastroenterol. 2017, 23, 590-602. [CrossRef] [PubMed]

74. Lowther, J.; Naismith, J.H.; Dunn, T.M.; Campopiano, D.J. Structural, mechanistic and regulatory studies of serine palmitoyltransferase. Biochem. Soc. Trans. 2012, 40, 547-554. [CrossRef] [PubMed]

75. Ingolia, N.T.; Hussmann, J.A.; Weissman, J.S. Ribosome Profiling: Global Views of Translation. Cold Spring Harb. Perspect. Biol. 2019, 11, a032698. [CrossRef] [PubMed]

76. Li, S. Regulation of Ribosomal Proteins on Viral Infection. Cells 2019, 8, 508. [CrossRef] [PubMed]

77. Subramani, C.; Nair, V.P.; Anang, S.; Mandal, S.D.; Pareek, M.; Kaushik, N.; Srivastava, A.; Saha, S.; Shalimar; Nayak, B.; et al. Host-Virus Protein Interaction Network Reveals the Involvement of Multiple Host Processes in the Life Cycle of Hepatitis E Virus. mSystems 2018, 3, e00135-17. [CrossRef] [PubMed]

78. Guca, E.; Hashem, Y. Major structural rearrangements of the canonical eukaryotic translation initiation complex. Curr. Opin. Struct. Biol. 2018, 53, 151-158. [CrossRef]

79. Todt, D.; Moeller, N.; Praditya, D.; Kinast, V.; Friesland, M.; Engelmann, M.; Verhoye, L.; Sayed, I.M.; Behrendt, P.; Thi, V.L.D.; et al. The natural compound silvestrol inhibits hepatitis E virus (HEV) replication in vitro and in vivo. Antiviral. Res. 2018, 157, 151-158. [CrossRef]

80. Glitscher, M.; Himmelsbach, K.; Woytinek, K.; Johne, R.; Reuter, A.; Spiric, J.; Schwaben, L.; Grunweller, A.; Hildt, E. Inhibition of Hepatitis E Virus Spread by the Natural Compound Silvestrol. Viruses 2018, 10, 301. [CrossRef]

81. Lee, J.S.; Tabata, K.; Twu, W.I.; Rahman, M.S.; Kim, H.S.; Yu, J.B.; Jee, M.H.; Bartenschlager, R.; Jang, S.K. RACK1 mediates rewiring of intracellular networks induced by hepatitis C virus infection. PLoS Pathog. 2019, 15, e1008021. [CrossRef]

82. LaFontaine, E.; Miller, C.M.; Permaul, N.; Martin, E.T.; Fuchs, G. Ribosomal protein RACK1 enhances translation of poliovirus and other viral IRESs. Virology 2020, 545, 53-62. [CrossRef]

83. Dobrikov, M.I.; Dobrikova, E.Y.; Gromeier, M. Ribosomal RACK1:Protein Kinase C betaII Modulates Intramolecular Interactions between Unstructured Regions of Eukaryotic Initiation Factor 4G (eIF4G) That Control eIF4E and eIF3 Binding. Mol. Cell. Biol. 2018, 38, e00306-18. [CrossRef] 
84. Kenney, S.P.; Meng, X.J. The lysine residues within the human ribosomal protein S17 sequence naturally inserted into the viral nonstructural protein of a unique strain of hepatitis E virus are important for enhanced virus replication. J. Virol. 2015, 89, 3793-3803. [CrossRef] [PubMed]

85. Shukla, P.; Nguyen, H.T.; Torian, U.; Engle, R.E.; Faulk, K.; Dalton, H.R.; Bendall, R.P.; Keane, F.E.; Purcell, R.H.; Emerson, S.U. Cross-species infections of cultured cells by hepatitis E virus and discovery of an infectious virus-host recombinant. Proc. Natl. Acad. Sci. USA 2011, 108, 2438-2443. [CrossRef] [PubMed]

86. Nguyen, H.T.; Torian, U.; Faulk, K.; Mather, K.; Engle, R.E.; Thompson, E.; Bonkovsky, H.L.; Emerson, S.U. A naturally occurring human/hepatitis E recombinant virus predominates in serum but not in faeces of a chronic hepatitis E patient and has a growth advantage in cell culture. J. Gen. Virol. 2012, 93, 526-530. [CrossRef] [PubMed]

87. Vasileiou, P.V.S.; Evangelou, K.; Vlasis, K.; Fildisis, G.; Panayiotidis, M.I.; Chronopoulos, E.; Passias, P.G.; Kouloukoussa, M.; Gorgoulis, V.G.; Havaki, S. Mitochondrial Homeostasis and Cellular Senescence. Cells 2019, 8, 686. [CrossRef]

88. Lai, J.H.; Luo, S.F.; Ho, L.J. Operation of mitochondrial machinery in viral infection-induced immune responses. Biochem. Pharmacol. 2018, 156, 348-356. [CrossRef]

89. Neumann, S.; El Maadidi, S.; Faletti, L.; Haun, F.; Labib, S.; Schejtman, A.; Maurer, U.; Borner, C. How do viruses control mitochondria-mediated apoptosis? Virus Res. 2015, 209, 45-55. [CrossRef]

90. Silwal, P.; Kim, J.K.; Kim, Y.J.; Jo, E.K. Mitochondrial Reactive Oxygen Species: Double-Edged Weapon in Host Defense and Pathological Inflammation During Infection. Front. Immunol. 2020, 11, 1649. [CrossRef] [PubMed]

91. Soomro, M.H.; Shi, R.; She, R.; Yang, Y.; Hu, F.; Li, H. Antigen detection and apoptosis in Mongolian gerbil's kidney experimentally intraperitoneally infected by swine hepatitis E virus. Virus Res. 2016, 213, 343-352. [CrossRef]

92. Liu, B.; Chen, Y.; Zhao, L.; Zhang, M.; Ren, X.; Zhang, Y.; Zhang, B.; Fan, M.; Zhao, Q.; Zhou, E.M. Identification and pathogenicity of a novel genotype avian hepatitis E virus from silkie fowl (gallus gallus). Vet. Microbiol. 2020, 245, 108688. [CrossRef]

93. Yang, Y.; Shi, R.; Soomro, M.H.; Hu, F.; Du, F.; She, R. Hepatitis E Virus Induces Hepatocyte Apoptosis via Mitochondrial Pathway in Mongolian Gerbils. Front. Microbiol. 2018, 9, 460. [CrossRef]

94. Qu, C.; Zhang, S.; Wang, W.; Li, M.; Wang, Y.; van der Heijde-Mulder, M.; Shokrollahi, E.; Hakim, M.S.; Raat, N.J.H.; Peppelenbosch, M.P.; et al. Mitochondrial electron transport chain complex III sustains hepatitis E virus replication and represents an antiviral target. FASEB J. 2019, 33, 1008-1019. [CrossRef]

95. Gotoh, T.; Terada, K.; Oyadomari, S.; Mori, M. hsp70-DnaJ chaperone pair prevents nitric oxide- and CHOP-induced apoptosis by inhibiting translocation of Bax to mitochondria. Cell Death Differ. 2004, 11, 390-402. [CrossRef] [PubMed]

96. Vazquez, C.; Horner, S.M. MAVS Coordination of Antiviral Innate Immunity. J. Virol. 2015, 89, 6974-6977. [CrossRef] [PubMed]

97. Yang, Y.; Liang, Y.; Qu, L.; Chen, Z.; Yi, M.; Li, K.; Lemon, S.M. Disruption of innate immunity due to mitochondrial targeting of a picornaviral protease precursor. Proc. Natl. Acad. Sci. USA 2007, 104, 7253-7258. [CrossRef] [PubMed]

98. Li, X.D.; Sun, L.; Seth, R.B.; Pineda, G.; Chen, Z.J. Hepatitis C virus protease NS3/4A cleaves mitochondrial antiviral signaling protein off the mitochondria to evade innate immunity. Proc. Natl. Acad. Sci. USA 2005, 102, 17717-17722. [CrossRef]

99. Yin, X.; Li, X.; Ambardekar, C.; Hu, Z.; Lhomme, S.; Feng, Z. Hepatitis E virus persists in the presence of a type III interferon response. PLoS Pathog. 2017, 13, e1006417. [CrossRef]

100. Xu, L.; Zhou, X.; Wang, W.; Wang, Y.; Yin, Y.; Laan, L.J.; Sprengers, D.; Metselaar, H.J.; Peppelenbosch, M.P.; Pan, Q. IFN regulatory factor 1 restricts hepatitis E virus replication by activating STAT1 to induce antiviral IFN-stimulated genes. FASEB J. 2016, 30, 3352-3367. [CrossRef]

101. Dong, C.; Zafrullah, M.; Mixson-Hayden, T.; Dai, X.; Liang, J.; Meng, J.; Kamili, S. Suppression of interferon-alpha signaling by hepatitis E virus. Hepatology 2012, 55, 1324-1332. [CrossRef]

102. Wissing, M.H.; Bruggemann, Y.; Steinmann, E.; Todt, D. Virus-Host Cell Interplay during Hepatitis E Virus Infection. Trends Microbiol. 2021, 29, 309-319. [CrossRef]

103. Lenggenhager, D.; Gouttenoire, J.; Malehmir, M.; Bawohl, M.; Honcharova-Biletska, H.; Kreutzer, S.; Semela, D.; Neuweiler, J.; Hurlimann, S.; Aepli, P.; et al. Visualization of hepatitis E virus RNA and proteins in the human liver. J. Hepatol. 2017, 67, 471-479. [CrossRef]

104. Paingankar, M.S.; Arankalle, V.A. Identification and characterization of cellular proteins interacting with Hepatitis E virus untranslated regions. Virus Res. 2015, 208, 98-109. [CrossRef]

105. Korkaya, H.; Jameel, S.; Gupta, D.; Tyagi, S.; Kumar, R.; Zafrullah, M.; Mazumdar, M.; Lal, S.K.; Xiaofang, L.; Sehgal, D.; et al. The ORF3 protein of hepatitis E virus binds to Src homology 3 domains and activates MAPK. J. Biol. Chem. 2001, 276, 42389-42400. [CrossRef] [PubMed]

106. Pingale, K.D.; Kanade, G.D.; Karpe, Y.A. Heterogeneous Nuclear Ribonucleoproteins Participate in Hepatitis E Virus Replication. J. Mol. Biol. 2020, 432, 2369-2387. [CrossRef]

107. Gonzalez, F.J. Regulation of hepatocyte nuclear factor 4 alpha-mediated transcription. Drug Metab. Pharmacokinet. 2008, 23 , 2-7. [CrossRef] [PubMed]

108. Chandra, V.; Holla, P.; Ghosh, D.; Chakrabarti, D.; Padigaru, M.; Jameel, S. The hepatitis E virus ORF3 protein regulates the expression of liver-specific genes by modulating localization of hepatocyte nuclear factor 4. PLoS ONE 2011, 6, e22412. [CrossRef]

109. Yamashita, T.; Mori, Y.; Miyazaki, N.; Cheng, R.H.; Yoshimura, M.; Unno, H.; Shima, R.; Moriishi, K.; Tsukihara, T.; Li, T.C.; et al Biological and immunological characteristics of hepatitis E virus-like particles based on the crystal structure. Proc. Natl. Acad. Sci. USA 2009, 106, 12986-12991. [CrossRef] [PubMed] 
110. Li, T.C.; Yamakawa, Y.; Suzuki, K.; Tatsumi, M.; Razak, M.A.; Uchida, T.; Takeda, N.; Miyamura, T. Expression and self-assembly of empty virus-like particles of hepatitis E virus. J. Virol. 1997, 71, 7207-7213. [CrossRef]

111. Xing, L.; Kato, K.; Li, T.; Takeda, N.; Miyamura, T.; Hammar, L.; Cheng, R.H. Recombinant hepatitis E capsid protein self-assembles into a dual-domain $\mathrm{T}=1$ particle presenting native virus epitopes. Virology 1999, 265, 35-45. [CrossRef]

112. Li, T.C.; Takeda, N.; Miyamura, T.; Matsuura, Y.; Wang, J.C.; Engvall, H.; Hammar, L.; Xing, L.; Cheng, R.H. Essential elements of the capsid protein for self-assembly into empty virus-like particles of hepatitis E virus. J. Virol. 2005, 79, 12999-13006. [CrossRef]

113. Xing, L.; Li, T.C.; Mayazaki, N.; Simon, M.N.; Wall, J.S.; Moore, M.; Wang, C.Y.; Takeda, N.; Wakita, T.; Miyamura, T.; et al. Structure of hepatitis E virion-sized particle reveals an RNA-dependent viral assembly pathway. J. Biol. Chem. 2010, 285, 33175-33183. [CrossRef]

114. Mori, Y.; Matsuura, Y. Structure of hepatitis E viral particle. Virus Res. 2011, 161, 59-64. [CrossRef] [PubMed]

115. Shiota, T.; Li, T.C.; Yoshizaki, S.; Kato, T.; Wakita, T.; Ishii, K. The hepatitis E virus capsid C-terminal region is essential for the viral life cycle: Implication for viral genome encapsidation and particle stabilization. J. Virol. 2013, 87, 6031-6036. [CrossRef]

116. Tam, A.W.; Smith, M.M.; Guerra, M.E.; Huang, C.C.; Bradley, D.W.; Fry, K.E.; Reyes, G.R. Hepatitis E virus (HEV): Molecular cloning and sequencing of the full-length viral genome. Virology 1991, 185, 120-131. [CrossRef]

117. Surjit, M.; Jameel, S.; Lal, S.K. The ORF2 protein of hepatitis E virus binds the 5 ' region of viral RNA. J. Virol. 2004, 78, 320-328. [CrossRef]

118. Guo, Y.; Sirkis, D.W.; Schekman, R. Protein sorting at the trans-Golgi network. Annu. Rev. Cell Dev. Biol. 2014, 30, 169-206. [CrossRef]

119. Nagashima, S.; Takahashi, M.; Jirintai, S.; Tanggis; Kobayashi, T.; Nishizawa, T.; Okamoto, H. The membrane on the surface of hepatitis E virus particles is derived from the intracellular membrane and contains trans-Golgi network protein 2. Arch. Virol. 2014, 159, 979-991. [CrossRef] [PubMed]

120. Tyagi, S.; Surjit, M.; Roy, A.K.; Jameel, S.; Lal, S.K. The ORF3 protein of hepatitis E virus interacts with liver-specific alpha1microglobulin and its precursor alpha1-microglobulin/bikunin precursor (AMBP) and expedites their export from the hepatocyte. J. Biol. Chem. 2004, 279, 29308-29319. [CrossRef] [PubMed]

121. Primadharsini, P.P.; Nagashima, S.; Takahashi, M.; Kobayashi, T.; Nishiyama, T.; Nishizawa, T.; Yasuda, J.; Mulyanto; Okamoto, H. Multivesicular body sorting and the exosomal pathway are required for the release of rat hepatitis E virus from infected cells. Virus Res. 2020, 278, 197868. [CrossRef]

122. Nagashima, S.; Jirintai, S.; Takahashi, M.; Kobayashi, T.; Tanggis; Nishizawa, T.; Kouki, T.; Yashiro, T.; Okamoto, H. Hepatitis E virus egress depends on the exosomal pathway, with secretory exosomes derived from multivesicular bodies. J. Gen. Virol. 2014, 95, 2166-2175. [CrossRef] [PubMed]

123. Surjit, M.; Oberoi, R.; Kumar, R.; Lal, S.K. Enhanced alpha1 microglobulin secretion from Hepatitis E virus ORF3-expressing human hepatoma cells is mediated by the tumor susceptibility gene 101. J. Biol. Chem. 2006, 281, 8135-8142. [CrossRef] [PubMed] 